\title{
Early Germination, Growth and Establishment of Khaya senegalensis (DESR.) A. Juss in Middle-Belt Zone of Nigeria
}

\author{
Zaccheus Tunde Egbewole ${ }^{1, ~ *, ~ O d u n a y o ~ J a m e s ~ R o t o w a ~}{ }^{2}$, Emmanuel Dauda Kuje ${ }^{1}$, \\ Oluwasola Abiodun Ogundana ${ }^{3}$, Hassan Haladu Mairafi ${ }^{1}$, Ibrahim Yohanna ${ }^{1}$ \\ ${ }^{1}$ Department of Forestry and Wildlife Management, Faculty of Agriculture, Nasarawa State University, Keffi, Nigeria \\ ${ }^{2}$ Department of Forest Production and Products, Faculty of Renewable Natural Resources, University of Ibadan, Ibadan, Nigeria \\ ${ }^{3}$ Department of Forestry Technology, Federal College of Forestry, Ibadan, Nigeria
}

\section{Email address:}

tundeegbe $@$ gmail.com (Z. T. Egbewole), tundeegbe 9 yahoo.com (Z. T. Egbewole)

${ }^{*}$ Corresponding author

\section{To cite this article:}

Zaccheus Tunde Egbewole, Odunayo James Rotowa, Emmanuel Dauda Kuje, Oluwasola Abiodun Ogundana, Hassan Haladu Mairafi, Ibrahim Yohanna. Early Germination, Growth and Establishment of Khaya senegalensis (DESR.) A. Juss in Middle-Belt Zone of Nigeria. Journal of Energy and Natural Resources. Vol. 7, No. 3, 2018, pp. 75-82. doi: 10.11648/j.jenr.20180703.11

Received: July 18, 2018; Accepted: August 29, 2018; Published: November 19, 2018

\begin{abstract}
A study was carried out to investigate the early growth and establishment of Khaya senegalensis in three different locations (Markurdi, Benue State, Lafia, Nasarawa state and Kwali, Abuja) within the middle belt zone of Nigeria in October 2014 with the aim to mass raising mahogany at economic scale. The study was carried out at the Department of Forestry, Wildlife and Ecotourism Nursery, Nasarawa State University Keffi, Shabu- Lafia Campus. The seeds were separately broadcasted on three different nursery beds and watered effectively. The parameter assessed include Plant height, Leaf count, Leave area and Collar girth. Data was analyzed using Analysis of variance and significant mean differences were separated at $p>0.05$. The results of parameter assessed on the basis of locations shows that seedlings from Makurdi had the highest mean height of $5.33 \pm 2.96 \mathrm{~cm}$ at 14 weeks after transplanting, closely followed by seedling from Kwali with mean height of $5.33 \pm 2.43 \mathrm{~cm}$ while seedling from Lafia had the least mean height of $5.29 \pm 2.46 \mathrm{~cm}$. The result of leave count revealed that seedling from Lafia had the highest leave count of 5.28 \pm 2.84 followed by Kwali with $5.25 \pm 3.00$ while leave count of seedlings from Makurdi had the least leave count of 5.18 \pm 3.0 . The result of growth variables revealed that, Khaya senegalensis saplings intercropped with cassava at Agroforestry plantation Plot had attained $2.415 \pm 0.45 \mathrm{~m}$ average height, $11.12 \pm 3.5 \mathrm{~cm}$ basal girth, $3.95 \pm 1.43 \mathrm{~cm} \mathrm{dbh}$, leaf count of $151.37 \pm 18.84$ within a period of $36 \mathrm{months}$ of planting on the field. The ANOVA result shows that there was significant difference in the leave count, leave length, collar girth and plant height from the three locations at $\mathrm{p}>0.05$, result of correlation analysis revealed that there was a significant correlation between leaf count and plant height $\left(0.78^{* *}\right)$, collar girth and leaf count $\left(0.67^{* *}\right)$. While the result of the regression analysis on the effects of growth variables on plant height had coefficient of $\mathrm{R}^{2}=0.67$, meaning that the assessed growth variables had about $67.4 \%$ effects on plant height of Khaya senegalensis seeds collected from different locations. The study reveals that seeds from different source demonstrated different growth performance, as it was observed that seeds obtained from Lafia performed better than the other two locations and as a result recommended for mass raising of Khaya senegalens within the middle-belt zone of Nigeria.
\end{abstract}

Keywords: Khaya senegalens, Collar Girth, Seedlings, Leave Count

\section{Introduction}

Khaya senegalensis A. Juss. (Melaceae), (mahogany) is the most suitable indigenous species for timber production in the world, growing up to $35 \mathrm{~m}$ in high and $1.5 \mathrm{~m}$ in a diameter on fertile soil, with an $10-16 \mathrm{~m}$ clean bole, its wood is hard, dense, reddish in colour and highly resistant to biodegradation. The wood has attractive colour, mostly straight grain orientation and a high luster. It is used for 
cabinetwork, ship building and in the production of decorative veneers Its natural regeneration is poor, especially with the problem of mahogany shoot borer (Moore) attack that usually prevents the success of plantations within the native area in West Africa [1]

The importance of forests and natural resources is indisputable, when considering the developing countries especially areas situated in the arid and semi-arid climatic zones. The woody species provide the main parts of the population with firewood and charcoal [2]. In the mid-fifties, forests in Sudan constituted about $36 \%$ of the total area Sudan is classified as a moderately forested country with about 28\% (67 million ha) forest and woodlands cover [3]. According to [4], the scarcity of forest resources in Nigeria is further aggravated by a high deforestation rate. Tropical forests are important to rural people in developing countries like Nigeria as they provide them with fuel and other essential goods and services, with food and benefit environment [5]. Khaya senegalensis locally known as Mahogany is one of the most economically important forest tree species. The tree is very popular, used for high-class furniture, joinery, building and construction purposes, and recommended for utilization purposes for which surface quality is of high importance. The species has also high traditional medicinal values and used as an ornamental tree for gardens and avenues.

The tree is native to Benin, Burkina Faso, Cameroon, Central African Republic, Chad, Ivory Coast, Gabon, Gambia, Ghana, Guinea, Guinea-Bissau, Mali, Niger, Nigeria, Senegal, Sierra Leone, Sudan, Togo, and Uganda. It is found in riparian forests and higher-rainfall savannah woodlands; in moist regions it is found on higher ground. Within its first year, the seedling develops a deep root system that makes it the most drought resistant member of its genus. Khaya senegalensis is insect pollinated. Flowering shortly before or early in the rainy season, the fruit apparently remaining on the tree throughout the dry season. When the fruit ripens, the colour changes from grey to black. Begins to bear seed when the tree is 20-25 years old. Seed may be dispersed up to $100 \mathrm{~m}$ by prevailing winds.

\section{Planting, Germination and Growing of Khaya senegalensis}

Natural regeneration from seed is poor, but fresh seed germinates readily when sown in a sand and peat mix in flat trays. Germination commences after about 10 to 14 days and high germination rates, usually around $90 \%$, can be expected when fresh seed is used. Seedlings can be picked out into deep containers and grown in the nursery until they reach 25 to $40 \mathrm{~cm}$ in height. They should be planted into the field early in the wet season after sufficient rain has fallen. Another method of planting stock is to use striplings or wildlings. These are small seedlings about 40 to $50 \mathrm{~cm}$ in height and about the thickness of a pencil, growing at the base of large mature trees [6]. During the wet season, individual seedlings can be pulled out of the ground and, after stripping the leaves and pruning the root section, they can be planted directly into the field after sufficient rain, or potted in containers. Seed for growing trees in plantations should be selected from good individuals with long straight trunks [7]. Khaya senegalensis will grow in a wide range of soil types. The $\mathrm{pH}$ tolerance can range between neutral to very strongly acidic; however, a neutral $\mathrm{pH}$ is more desirable [3]. It prefers well-drained soils. Sandy loams are ideal, whereas poorly-drained clays or duplex soils should be avoided. It should not be planted in shallow soils as this will prevent the large taproot from developing and anchoring the tree.

Many factors were attributed to the deforestation in Nigeria such as agricultural expansion, indiscriminate bush burning, overgrazing and illicit felling of trees for fuel wood. Nigeria's forests provide a variety of goods including timber in the round and sawn forms arboreal biomass for domestic energy supplies and building material and a large number of Non-Wood Forest Products (NWFPs) National energy surveys indicated that forests provides $70.8 \%$ of the country national energy balance (4.01 million tons of oil equivalents) [8]. In addition, forestry activities provide significant opportunities for employment and income generation in almost all rural areas of Nigeria. It was estimated that one out of seven of the population is engaged in forest related activities [9]. The forest and woodland area in Nigeria amount to 68.90 million ha, which is continuously being encroached into by agriculture and urbanization or otherwise degraded by uncontrolled felling [10]. In view of the potentials of Khaya senegalensis (mahogany), the rate at which the tree species is being felled for commercial and other purposes is too high whereas the regeneration and afforestation of the tree species is low. This study therefore focused on mass rising of Khaya senegalensis (Mahogany) at economic scale to improve the regeneration and afforestation of the tree species.

\section{Materials and Method}

\subsection{Study Area}

The experiment was carried out at the Department of Forestry Wildlife and Ecotourism Nursery while the plantation establishment was done Agroforestry Demonstration Plot, Nasarawa State University Keffi, ShabuLafia Campus. Lafia is located in the Guinea savannah zone of North Central Nigeria and found on latitude $08^{\circ} 35^{\prime} \mathrm{N}$, longitude $08^{\circ} 32^{\prime} \mathrm{E}$, altitude $181.53 \mathrm{~m}$ above sea level with a mean temperature of $34^{\circ} \mathrm{C}$, relative humidity of $40-86 \%$ and average day light of 9-12hours.

\subsection{Materials and Methods}

The Khaya senegalensis seeds were collected from different mother trees from three different locations within the middle belt region of Nigeria in October 2014 (Figure 1). Viz; Makurdi, Benue State, Lafia, Nasarawa State and Kwali, 
FCT. The seeds were broadcasted on three different nursery bed, prepared, mulch material were put on the nursery beds to keep the soil moist. The nursery beds were watered twice everyday (morning and evening). After 10days of continuous watering, the first germination was observed on Lafia beds and full germination was noticed after 16days of planting on all the beds. From each of the nursery beds, three hundred (300) seedlings of, K. senegalensis were planted in Polythene pot of size $15 \times 20 \mathrm{~cm}$ making a total of 900 seedlings per location used for the study (Figure 3). After transplanting, watering was done once daily, manual weeding was carried out once per week. Survival test was carried out on the seedlings to determine its viability after transplanting (Figure 4). Survival rate was observed for about four weeks and estimated thus:

$$
\% \text { survival test }=\frac{\text { Number of survived seedlings } \times 100}{\text { Total number if seed sown }}
$$

\subsection{Data Collection and Analysis}

Collection of data was basically field observation and recording. The young seedlings which were transplanted into polythene pots with 300 seedlings selected from total seed raised (Figure 2-5). The growth parameters assessed include: Plant height $(\mathrm{cm})$; Leaf count, Collar girth $(\mathrm{cm})$ Leave area $\left(\mathrm{m}^{2}\right)$ (Figure 5). The experiment was one factor and randomly assigned into three (3) different locations with each location containing three hundred (300) seedlings. Data was analyzed using Analysis of variance (ANOVA) and significant mean differences were separated at 0.05 probability level as described by [11]. Correlation analysis was used to establish the relationship between the growths parameters of three (3) different locations. Mature seedlings ready for plantation establishment at 4 months (Figure 6) was transferred to the plantation. While assessment of Khaya $s$. under agroforestry scheme was carried out annually for 3years (Figure $7 \& 8$ ).

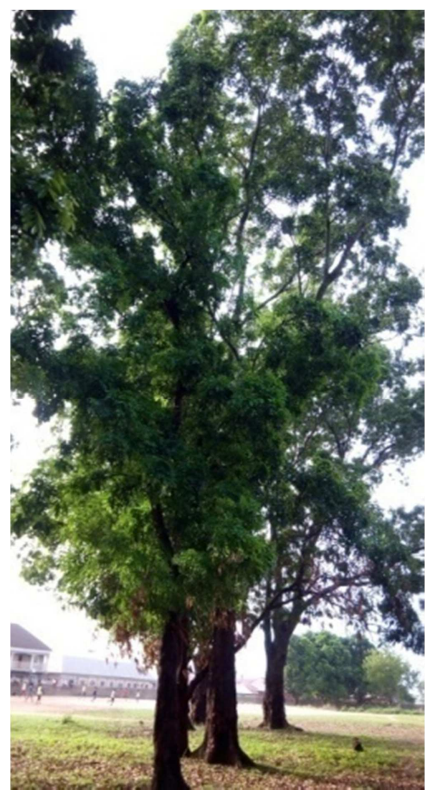

Figure 1. Matured stand of Khaya senegalensis.

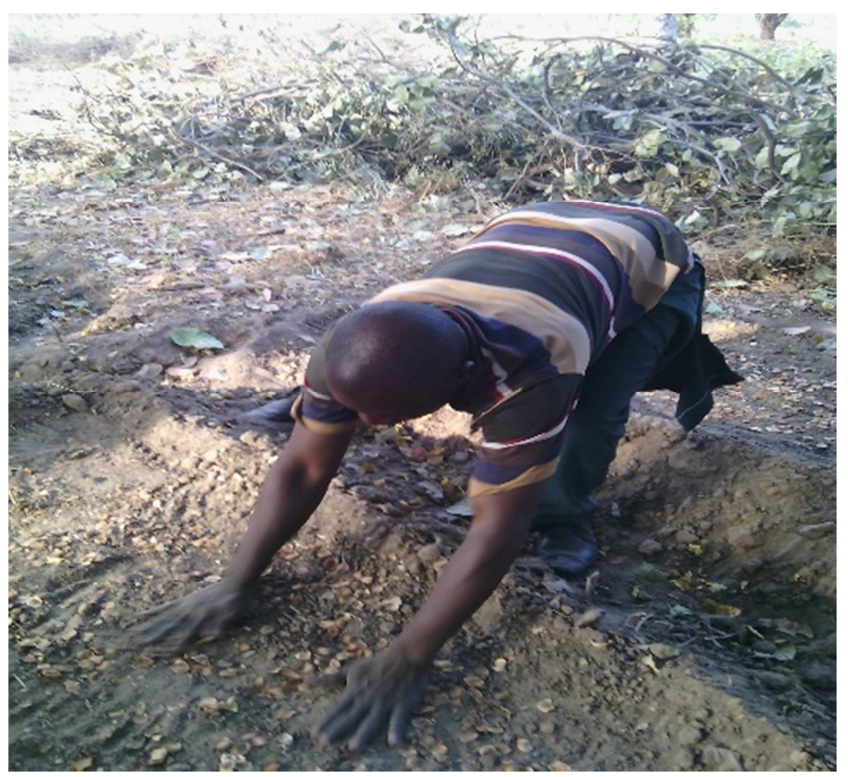

Figure 2. Sowing of Khaya senegalensis seeds.

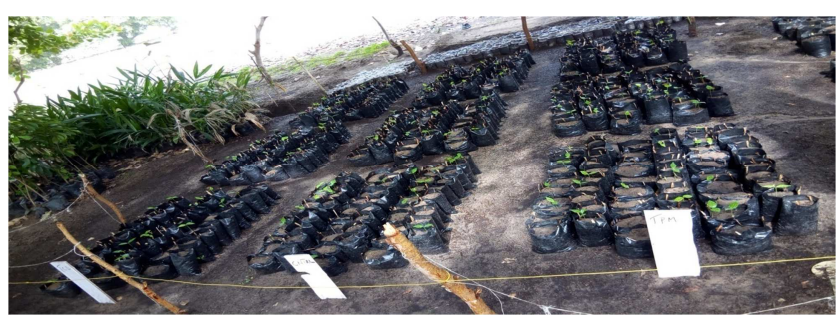

Figure 3. Experimental Layout according to locations.

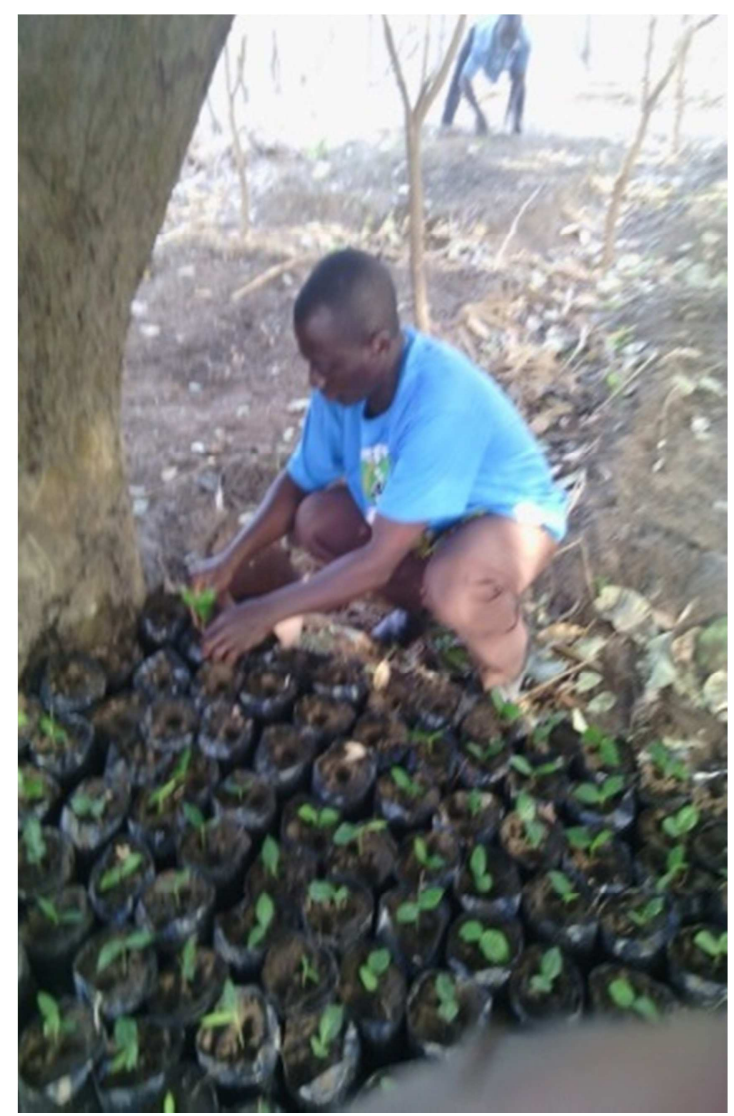

Figure 4. Transplanting of K. senegalensis seedlings (4WAP). 


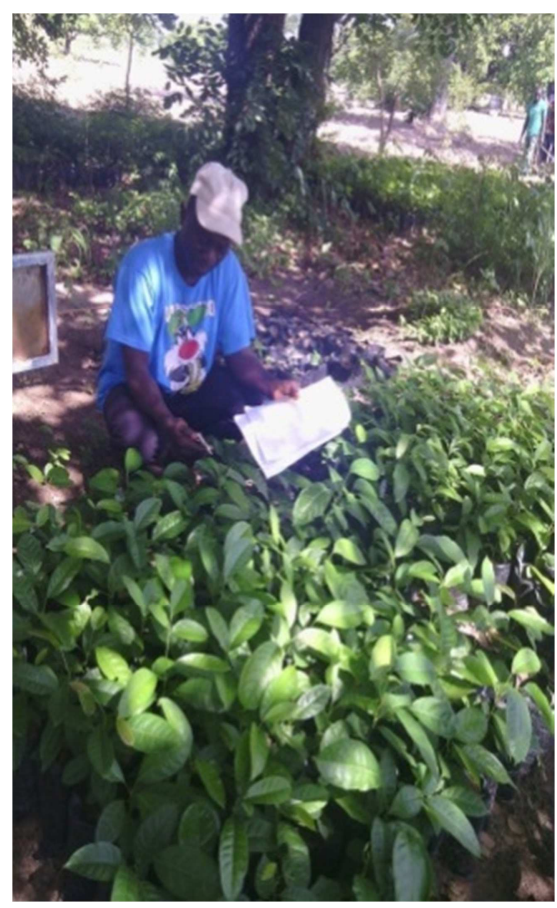

Figure 5. Data collection (5WAT).

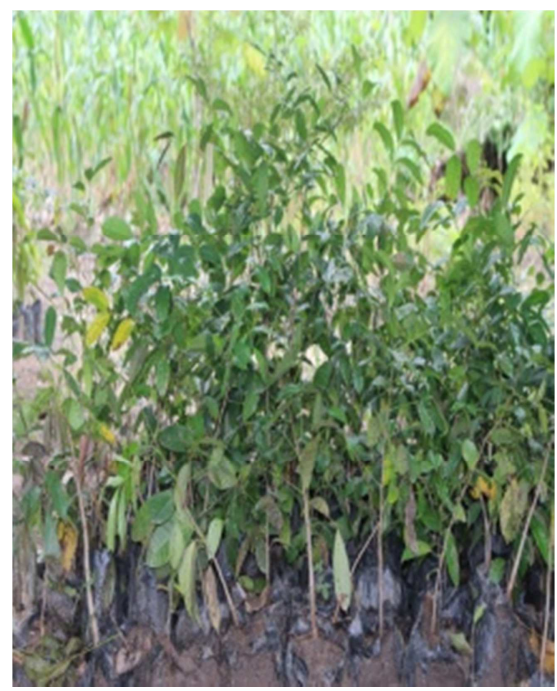

Figure 6. Mature seedlings ready for plantation establishment at 4months.

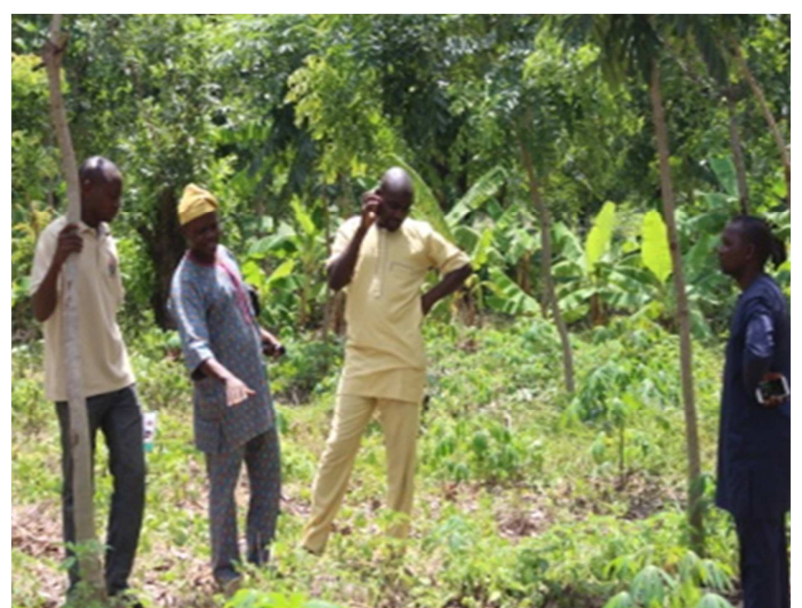

Figure 7. Assessment of Khaya s. under agroforestry scheme.

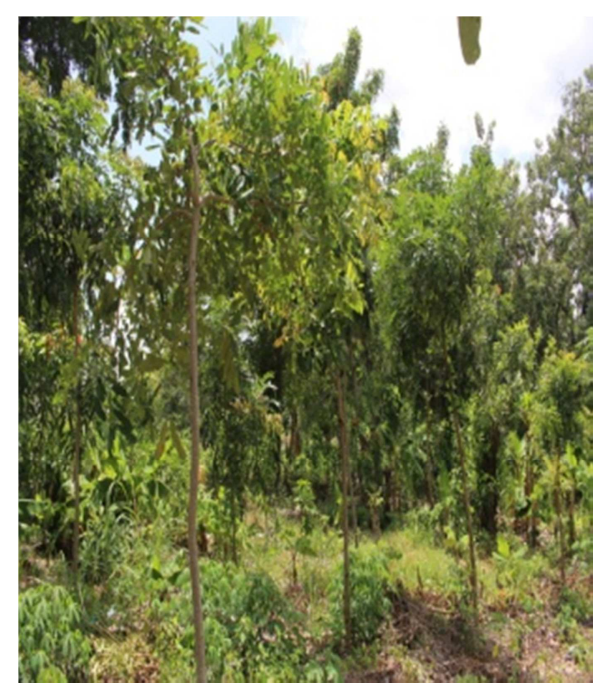

Figure 8. Established Khaya senegalensis saplings at Agroforestry plot (3years).

\section{Results}

\subsection{Result of Mean Values of Parameter Assessed at Nursery Stage}

The mean result of parameter assessed on the basis of locations and weeks was shown in Table 1, seedling from Makurdi had the highest mean height value of $5.33 \pm 2.96 \mathrm{~cm}$ at 14 weeks after transplanting, closely followed by seedling from Kwali with mean height value of $5.33 \pm 2.43 \mathrm{~cm}$ while seedling from Lafia had the least mean value of $5.29 \pm 2.46$ $\mathrm{cm}$. The result of collar girth shows that seedling from Lafia had the highest mean collar girth of $0.52 \pm 0.36 \mathrm{~cm}$ followed by seedling from Makurdi with collar girth value $0.51 \pm 0.33$ $\mathrm{cm}$ while seedling from kwali had the least collar girth $0.49 \pm 0.37 \mathrm{~cm}$. Seedling from Lafia had the highest leave length $5.31 \pm 2.39 \mathrm{~cm}$, followed by seedling from Makurdi $5.07 \pm 2.39 \mathrm{~cm}$ while seedling from Kwali again had the least leave length $4.81 \pm 2.54 \mathrm{~cm}$. The result of leave count (Number of leaves) reveals that seedling from Lafia had the highest leave count of $5.28 \pm 2.84$ followed by Kwali with mean value $5.25 \pm 3.00$ while leave count from Makurdi had the least leave count of $5.18 \pm 3.0$.

The result of weekly performance shows that, week 14 had the highest mean value of plant height with $8.57 \pm 1.37 \mathrm{~cm}$ followed by week 10 with mean value of $5.75 \pm 0.73 \mathrm{~cm}$ while week 4 had the least height value of $2.68 \pm 0.39 \mathrm{~cm}$ this shows that the higher the period the higher the increase in height of Khaya senegalensis. This result therefore agree with the study of [13] who recorded an increase in the growth of Africa mahogany raised in the nursery after 120 days, week 14 had the highest collar girth of $0.98 \pm 0.33 \mathrm{~cm}$ followed by week 10 with collar girth value of $0.48 \pm 0.10 \mathrm{~cm}$ meanwhile, week 4 had the least collar girth of $0.15 \pm 0.05 \mathrm{~cm}$. Also, week 14 had the highest leave length value of $8.44 \pm 1.52 \mathrm{~cm}$ again followed by week 10 with leave length value of $5.50 \pm 1.19$ $\mathrm{cm}$ and week 4 had the least value of leave length with $1.99 \pm 0.64 \mathrm{~cm}$. The trend continues in leave numbers as week 
14 had the highest mean value of leave count $(9.16 \pm 1.39)$ followed by week 10 with leave count of $6.10 \pm 1.02$ while week 4 again had the least value of leave count $1.59 \pm 0.59$ (Table 1).

Table 1. Means value of parameter assessed on the seedlings at nursery per location and weeks.

\begin{tabular}{|c|c|c|c|c|c|}
\hline S/No & Source of variation & Plant height (cm) & Collar girth $(\mathrm{cm})$ & Leave length $(\mathrm{cm})$ & Leave count \\
\hline & Location & & & & \\
\hline 1 & Kwali & $5.33 \pm 2.43^{\mathrm{a}}$ & $0.49 \pm 0.37^{\mathrm{a}}$ & $4.81 \pm 2.54^{\mathrm{a}}$ & $5.25 \pm 3.00^{\mathrm{a}}$ \\
\hline 2 & Lafia & $5.29 \pm 2.46^{\mathrm{a}}$ & $0.52 \pm 0.36^{\mathrm{a}}$ & $5.31 \pm 2.39^{\mathrm{a}}$ & $5.28 \pm 2.84^{\mathrm{a}}$ \\
\hline 3 & $\begin{array}{l}\text { Makurdi } \\
\text { Weeks }\end{array}$ & $5.33 \pm 2.96^{\mathrm{a}}$ & $0.51 \pm 0.33^{\mathrm{a}}$ & $5.07 \pm 2.39^{\mathrm{a}}$ & $5.18 \pm 3.01^{\mathrm{a}}$ \\
\hline 1 & 4 & $2.68 \pm 0.39^{\mathrm{a}}$ & $0.15 \pm 0.05^{\mathrm{a}}$ & $1.99 \pm 0.64^{\mathrm{a}}$ & $1.59 \pm 0.59^{\mathrm{a}}$ \\
\hline 2 & 7 & $4.75 \pm 0.73^{\mathrm{c}}$ & $0.40 \pm .0 .10^{\mathrm{b}}$ & $4.32 \pm 1.19^{\mathrm{b}}$ & $4.10 \pm 0.82^{b}$ \\
\hline \multirow[t]{2}{*}{4} & 14 & $8.57 \pm 1.37^{\mathrm{d}}$ & $0.98 \pm 0.33^{\mathrm{d}}$ & $8.44 \pm 1.52^{\mathrm{d}}$ & $9.16 \pm 1.39^{\mathrm{d}}$ \\
\hline & Grand mean & $5.31 \pm 2.61$ & $0.50 \pm 0.35$ & $5.06 \pm 3.29$ & $5.23 \pm 2.95$ \\
\hline
\end{tabular}

Note: Mean with the same alphabet on the same column is not significantly different at $\mathrm{p}<0.05$

Table 2. Mean values of Growth rate of Khaya senegalensis at Agroforestry Plot.

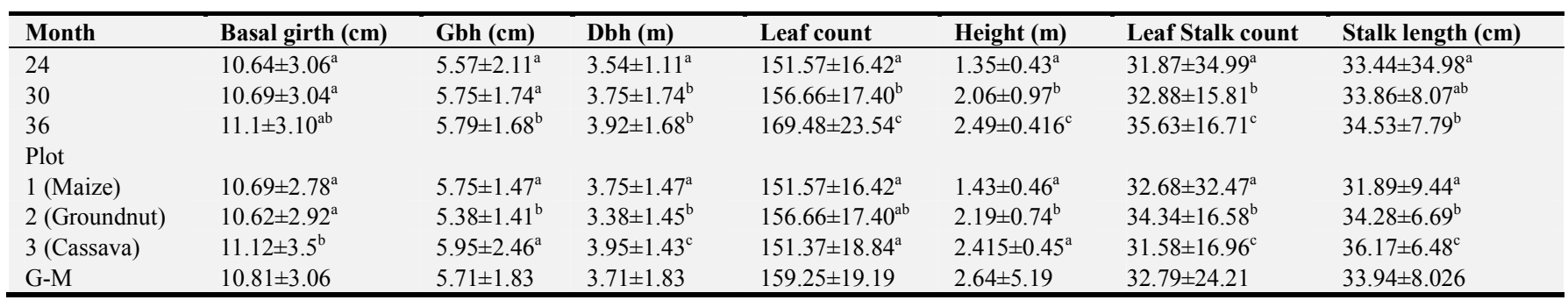

Note: Mean with the same alphabet on the same column is not significantly different at $\mathrm{p}<0.05$

\subsection{Result of Mean Values of Growth Performance Rate of Khaya senegalensis at Agroforestry Plot}

The result of growth variables revealed that, Khaya senegalensis saplings intercropped with cassava at Agroforestry plantation Plot had attained $2.415 \pm 0.45 \mathrm{~m}$ average height, $11.12 \pm 3.5 \mathrm{~cm}$ basal girth, $3.95 \pm 1.43 \mathrm{~cm} \mathrm{dbh}$, leaf count of $151.37 \pm 18.84$ within a period of 36 months of planting on the field. The saplings intercropped with groundnut had attained $2.19 \pm 0.74 \mathrm{~m}$ height, $10.62 \pm 2.92 \mathrm{~cm}$ basal girth, $3.38 \pm 1.45 \mathrm{~cm}$ dbh, leaf count of $156.66 \pm 17.40$. While the least growth performance of Khaya senegalensis was observed in the saplings intercropped with maize which had attained $1.43 \pm 0.46 \mathrm{~m}$ average height, $10.69 \pm 2.78 \mathrm{~cm}$ basal girth, $3.75 \pm 1.47 \mathrm{~cm} \mathrm{dbh}$, leaf count of $151.57 \pm 16.42$ within a period of 36 months of planting on the field. The results of ANOVA showed that the effect of intercropping on the growth performance of Khaya senegalensis saplings was significant on plant height, basal girth, dbh and leaf count at $\mathrm{p}<0.05$ (Table 2).

\subsection{ANOVA and Correlation Result on Parameter Assessed}

The results of analysis of variance of all the parameter accessed (number of leaves, leave length, collar girth and plant height) indicated that location and weeks significantly influenced germination rate of Khaya senegalensis, $\left(0.00^{* *}\right)$ at $p>0.05$ (Table 3 ). The ANOVA result shows that there was significant difference in the leave count, leave length, collar girth and plant height from the three locations at $\mathrm{p}>0.05$. (Table 3). Result of correlation analysis revealed that there was a significant correlation between leaf count and plant height $\left(0.78^{* *}\right)$, between the collar girth and week $(0.81 * *)$, collar girth and leaf count $(0.67 * *)$, weeks and plant height $\left(0.82^{* *}\right)$ (Table 4$)$. The result of the regression analysis on the effects of growth variables on plant height had coefficient of $\mathrm{R}^{2}=0.67$ (Table 5) meaning that the assessed growth variables had about $67.4 \%$ effects on plant height of Khaya senegalensis seed collected from different locations in middle belt region of Nigeria.

Table 3. Analysis of variance for leave count, Leave length, Collar girth and Plant Height.

\begin{tabular}{|c|c|c|c|c|c|c|}
\hline Source & Sum of Squares & df & Mean Square & $\mathbf{F}$ & Sig. & $\mathbf{R}^{2}$ \\
\hline \multicolumn{7}{|l|}{ leave count } \\
\hline Location & 0.749 & 2 & 0.37 & 0.36 & $0.04 *$ & \multirow{9}{*}{0.88} \\
\hline Week & 2763.11 & 3 & 2.04 & 6.37 & $0.00^{* *}$ & \\
\hline location * week & 3.44 & 6 & 0.57 & 0.57 & $0.76^{\mathrm{ns}}$ & \\
\hline Error & 353.63 & 348 & 1.01 & & & \\
\hline Total & 3120.93 & 359 & & & & \\
\hline Leave length & & & & & & \\
\hline Location & 15.16 & 2 & 7.58 & 1.42 & $0.04 *$ & \\
\hline Week & 1946.16 & 3 & 648.72 & 121.42 & $0.00 * *$ & \\
\hline location * week & 64.37 & 6 & 10.73 & 2.01 & $0.06^{\mathrm{ns}}$ & \\
\hline
\end{tabular}




\begin{tabular}{|c|c|c|c|c|c|c|}
\hline Source & Sum of Squares & df & Mean Square & $\mathbf{F}$ & Sig. & $\mathbf{R}^{2}$ \\
\hline Error & 1859.34 & 348 & 5.34 & & & \\
\hline Total & 3885.03 & 359 & & & & 0.52 \\
\hline Collar girth & & & & & & \\
\hline Location & 0.06 & 2 & .028 & .811 & $0.04 *$ & \\
\hline Week & 32.92 & 3 & 10.97 & 316.85 & $0.00 * *$ & \\
\hline location * week & 0.23 & 6 & .039 & 1.128 & $0.34^{\mathrm{ns}}$ & \\
\hline Error & 12.05 & 348 & .035 & & & \\
\hline $\begin{array}{l}\text { Corrected Total } \\
\text { Plant Height }\end{array}$ & 45.26 & 359 & & & & 0.73 \\
\hline Location & 0.13 & 2 & 0.06 & 0.02 & $0.05^{*}$ & \\
\hline Week & 1693.54 & 3 & 564.51 & 261.42 & $0.00 * *$ & \\
\hline location * week & 18.59 & 6 & 3.10 & 1.44 & $0.20^{\mathrm{ns}}$ & \\
\hline Error & 751.45 & 348 & 2.16 & & & \\
\hline Total & 2463.71 & 359 & & & & 0.69 \\
\hline
\end{tabular}

Note: ${ }^{*}$ Highly Significant at $1 \%$ probability level $\mathrm{p}<0.05,{ }^{*}=$ Significant, $\mathrm{ns}=$ not significant

Table 4. Correlation analysis for parameters assessed.

\begin{tabular}{llllll}
\hline & week & collar girth & leave length & leave count & plant height \\
\hline Week & 1 & & & & \\
Collar girth & $0.81^{* *}$ & 1 & & & \\
Leave length & $0.699^{* *}$ & $0.582^{* *}$ & 1 & 1 & \\
leave count & $0.938^{* *}$ & $0.779^{* *}$ & $0.668^{* *}$ & $0.783^{* *}$ & 1 \\
plant height & $0.818^{* *}$ & $0.710^{* *}$ & $0.583^{* *}$ & \\
\hline
\end{tabular}

$* *=$ correlation is significant at $1 \%$ level $\mathrm{p}<0.01, *=$ correlation is significant at $5 \%$ level $\mathrm{p}<0.05$

Note: $* *=$ highly significant at $1 \%$ probability level, $*=$ significant at $\mathrm{p}<0.05, \mathrm{~ns}=$ not

Table 5. Linear regression analysis of variables assessed.

\begin{tabular}{|c|c|c|c|c|c|c|c|c|}
\hline \multirow{2}{*}{ Model } & & \multicolumn{2}{|c|}{ Unstandardized Coefficients } & \multirow{2}{*}{$\begin{array}{l}\text { Standardized Coefficients } \\
\text { Beta }\end{array}$} & \multirow{2}{*}{$\mathbf{t}$} & \multirow{2}{*}{ Sig. } & \multirow[b]{2}{*}{ S.E.E } & \multirow[b]{2}{*}{$\mathbf{R}^{2}$} \\
\hline & & B & Std. Error & & & & & \\
\hline \multirow{4}{*}{1} & (Constant) & 4.15 & 0.22 & & 18.73 & $0.000^{* *}$ & & \\
\hline & Collar girth & -0.01 & 0.01 & -0.02 & -1.11 & $0.270^{*}$ & & \\
\hline & Week & -0.21 & 0.05 & -0.21 & -4.72 & $0.000^{* *}$ & & \\
\hline & Collar Girth & 4.97 & 0.44 & 0.57 & 11.40 & $0.000^{* *}$ & 1.98 & 0.674 \\
\hline
\end{tabular}

Note: $* *=$ highly significant at $\mathrm{p}<0, *=$ significant at $\mathrm{p}<0.05$, ns $=$ not significant

Dependent variable: Plant Height, S.E.E means Standard Error Estimate

\section{Discussion}

Physical characteristics are the visually determinable attributes of tree seedlings in nursery. the major morphological criteria often used to describe timber seedling potentials are shoot height, leaf number, seedling collar diameter, leaf area, root mass and plant root ratio. These are some of the bases to qualify good seedlings for nursery establishment. The result of weekly performance shows that, week 14 had the highest mean value of plant height with $8.57 \pm 1.37 \mathrm{~cm}$ followed by week 10 with mean value of $5.75 \pm 0.73 \mathrm{~cm}$ while week 4 had the least height value of $2.68 \pm 0.39 \mathrm{~cm}$ this shows that the higher the duration of data collection the higher the increase in height of Khaya senegalensis for a giving period. This result therefore agree with the study of [12] in 2011who recorded an increase in the growth of Africa mahogany raised in the nursery after 120 days. This is also in conformity with reports on plantation trees like Micheliachapaca L, Tectonia grandis Teak, and Entandrophragma cylindricum [13; 14]. Similar positive results have been reported on growth performance of timber seedlings $[15 ; 16]$. Growth in heights of seedlings showed differences in early growth trail of Khaya senegalensis $(\mathrm{p}<$
0.05). This is in conformity with results obtained by [17] in his study on regeneration patterns of Cedrela liloi (Meliaceae) in North western Argentina Subtropical Montane Forest, it also corroborate the findings of [18] in their study on Utilization of seed reserves during germination and early seedling growth by Dryobalano planceolata (Dipterocarpaceae). Height increments were highest with treatment and the combination of different location. The variation in the growth variables could be attributed to the fact that the seeds gotten from different locations has different viability due to its inherent climatic traits from the mother plant, while the significant effect of seeds sources on virtually all the variables measured could be attributed to the fact that the seeds might have inherent climatic traits similar results have been. There were no significant differences in the number of leaves produced by seedlings during the experiment base on location. However, it was significant base on weekly assessment. This correlate with [19] who reported that there was no significant different in the mean value of plant height, leaf count, branch count and collar girth in relative to level in a study he carried out on Moringa oleifera. 


\section{Summary and Other Findings}

In the result of fertilizer application of early growth trails of different forest tree species, [20] worked with Eucalyptus globules, reported that seedling collar diameter increment did not show significant differences $(\mathrm{P}>0.05)$ even with nutrient application. Seedling collar diameter increments for fertilized seedlings were generally better than those of the controlled experiment. [21] Also reported similar results for tree seedlings. The combination which yielded the best diameter increments was Lafia seeds at $14^{\text {th }}$ week, indicating that the seeds gotten from different locations have different viability due to its inherent climatic traits from the mother plant. This could be attributed to the fact that the seeds might have inherent climatic traits by means of stimulating growth formation, rapid cell division and differentiation resulting in collar diameter increment $[15 ; 22]$. The result of the experiment also show that there is a significant increase due to the different location on the growth parameters on the Khaya senegalensis seedlings with mean values of height $5.31 \pm 2.61 \mathrm{~cm}$, collar girth $0.50 \pm 0.35 \mathrm{~cm}$, leaf number $5.23 \pm 2.95$ and leaf length $5.06 \pm 3.29 \mathrm{~cm}^{2}$, the response of these characters to the different locations could be attributed to the fact that seeds gotten from different locations has different viability due to its inherent climatic traits from the mother plant, while the significant effect of seeds sources on virtually all the variables measured could be attributed to the fact that the seeds might have inherent climatic traits that lead to rapid germination and establishment of the seed, therefore the seedlings started receiving sunlight and absorbing nutrients first that lead to the significant difference in the growth parameters. [23] Also observed this in the assessment of germination and early growth trial of Gmelina arborea, [24].

\section{Conclusion and Recommendation}

\subsection{Conclusion}

There is no doubt that Khaya senegalensis is predominately strives well in savanna wood land of guinea zone including transition types of the forest zone as it is the most suitable indigenous species for timber production in BurkinaFaso, growing up to $35 \mathrm{~m}$ in height and $1.5 \mathrm{~m}$ in diameter on fertile soil with $16-18 \mathrm{~cm}$ clean bole which has over the years been replicated in Nigeria successfully. Its wood is hard dense and red, resistance making cabinet work, ship build, wood houses, and production of decorative veneers. Base on the result of the study therefore, it was discovered from the analysis result that the plants grows as the week increases and that location had significant effects on the early growth and survival of mahogany (Khaya senegalensis) seeds as the locations were significantly different from one another. Seeds from different source has different viability, as it was observed that seeds obtained from Lafia were more viable than the other collected from Makurdi and Abuja, therefore when raising Khaya senegalensis for plantation establishment, the source of seed collection should be considered as a factor.

\subsection{Recommendations}

From the result of the study, it is recommended that:

(i) Seeds from Lafia should be adopted in raising Khaya senegalensis seedlings in the nursery establishment within middle belt, Nigeria.

(ii) further research activities on pretreatment of seed of Khaya senegalensis should be carried out to improve raising the species for plantation establishment purpose.

(iii) Care should be taken to locate appropriate seed source as this will go a long way to increase the production of Khaya senegalensis trees and guarantee its sustainable supply to forest industries.

(iv) further research activities on effects of intercropping on the early growth performance of Khaya senegalensis saplings

(v) Finally, further studies should be carried out on the percentage survival rate of Khaya senegalensis seedlings and saplings in middle belt in Nigeria under a longer study period.

\section{Acknowledgements}

Authors are grateful to the Students of the Department of Forestry, Wildlife and Ecotourism and the Management of the Faculty of Agriculture, Nasarawa State University Keffi, for providing a conducive environment to carry out this research work.

\section{References}

[1] Nikiema and Pasternak, D. (2008). Khaya senegalensis (Desr) A. juss. in; louppe, D, oteng-Pinkard EA, Ballie C, Patel V, Mohammed CL (2007). Effects of fertilizing with Nitrogen and Phosphorus on growth and crown condition of Eucalyptus globolus Labill. Experiencing insect defoliation. For. Ecol. Manage., 231: 131-137.

[2] Plaza, A. and Chang, C. 2008. High performance computing in remote sensing. Chapman andHall/CRC, Taylor and Francis Group, LLC. 465, 544-553. Department, FAO, Rome.

[3] GFRA, (2005). Global Forest Resources Assessment. Country report 212: Sudan, Forestry Department.

[4] FAO, (2003). State of the world's forests, Rome, Italy. Department, FAO, Rome.

[5] Badi, K. H. (1989.) The natural forests. In: The forest of the Sudan, Khartoum, Sudan.

[6] IUCN (2006) Red List of Threatened Species. World Conservation Monitoring Centre 1998. Joffe, Pitta: (2007), Indigenous Plants of South Africa, Briza Publications, pg 123.

[7] Mahhoub, S. (2002): Studies of physiological, Environmental and of some forest tree species. Ph.D. Thesis, U. K.

[8] FAO, (2003). State of the world's forests, Rome, Italy. Department, FAO, Rome. 
[9] Bargali K, Tewari A (2004). Growth and water relation parameters in drought-stressed. Coriaria. Bungard RA, Press MC, Scholes JD (2000). The influence of nitrogen on rain forest Dipterocarp seedlings exposed to large increaseirradiance. Plant, Cell Environ, 23: 1183-1194.

[10] Salih, A. A. M. (2000). Forestry outlook study for Africa, Sudan Forest National Corporation. Khartoum, Sudan.

[11] Steel R. G. D., Torrie D. A and Dickey D. A (1997). Principles and produce of statistics: A biometric approach $3^{\text {rd }}$ ed. McGraw Hill Book Co. Inc. New York: 400-428.

[12] Focho D. A, Eneke B, Egbe A, Fongod A. G, Fonge B. A and Njoh R. N. (2011). Effects of organic and inorganic fertilizers on early growth characteristics of Khaya ivorensis Chev (African mahogany) in nursery. African Journal of Plant Science Vol. 5 (12), pp. 722-729, Available online at http://www.academicjournals.org/AJPS ISSN 1996-0824 C2011 Academic Journals.

[13] Hall J. S, Mark P, Astone S, Graeme P (2003). Seedling performance of four sympatric Entandrophragma species (Meliaceae) under stimulated fertility and moisture regimes of a Central African Rainforest. J. Tropical Ecol., 19: 55-66.

[14] Wilson; T. B and Witkowski ETF. 1998. Water requirement for germination and changes in higher plants. CR Biol. 331: 215-225.

[15] Bungard RA, Press MC, Scholes JD (2000). The influence of nitrogen on rain forest Dipterocarp seedlings exposed to large increase irradiance. Plant, Cell Environ, 23: 11831194.changes in higher plants. CR Biol. 331: 215-225.

[16] Kolawole, S. O. Kolawole O. T. and M. A. Akanji, M. A. (2011). Effects of Aqueous Extract of Khaya senegalensis Stem Bark on Biochemical and Hematological Parameters in Rats. Journal of Pharmacology and Toxicology, 6: 602-607.
[17] Hector R. G (2000). Regeneration patterns of Cedrela liloi (Meliaceae) in North western Argentina Subtropical Montane Forest. J. Trop. Ecol., 16:227-242.

[18] Ichie T, Ninomiya I, Ogino K (2001). Utilization of seed reserves during germination and early seedling growth by Dryobalanoplanceolata (Dipterocarpaceae). J. Trop. Ecol., 17: 371-378.

[19] Rotowa, O. J., Ugonma, D. A., Egbewole, Z. T. and Bhadmus, H. B. (2017). Growth Response of Moringa oleifera Lam. to Organic and Mineral Fertilizers Treatment. International Journal of Applied Research and Technology. 6 (5): 51-56.

[20] Pinkard EA, Ballie C, Patel V, Mohammed CL (2007). Effects offertilizing with Nitrogen and Phosphorus on growth and crowncondition of Eucalyptus globolus Labill. Experiencing insect defoliation. For. Ecol. Manage., 231: 131-137.

[21] Gbadamosi A. E (2006). Fertilizer response in seedlings of medicinal Enantiachloranthaoliv. Trop. Subtrop. Ecosystem, 6: $11-115$.

[22] Hoque ATMR, Hossian MK, Mohiuddin M, Hoque MM (2004). Effect ofinorganic fertilizers on initial growth performance of Micheliachampaca Linn. Seedling in Nursery. J. Biol. Sci., 4: 489-497.

[23] Egbewole Z. T., Elabor A. A. and Akinyemi O. (2015): Assessment of Germination and Early Growth Trial of Gmelina arborea (Roxb.). NSUK Journal of Science and Technology (NJST). Publication of Nasarawa State University, Keffi.www.njst@nsuk.edu.ngVol. 5 (1), 2015.ISSN 15975527.pp214-223.

[24] Agboola, D. A and Etejere E. O. (1991): Studies on Seed Dormancy of Selected Economic Tropical Tree Species: Nigeria Journal of Botany 8: 45-56. 